\title{
The present situation of Rare Diseases in Central/ Eastern Europe? The role of patient organisations
}

\author{
Gabor Pogany \\ From 5th European Conference on Rare Diseases (ECRD 2010) \\ Krakow, Poland. 13-15 May 2010
}

Our goal was to introduce the limited available comparative data to characterise the situation in Central/ Eastern Europe in the field of rare diseases. We collected the most important observations of current international surveys which were performed with or without the involvement of member associations of EURORDIS.

\section{Results}

1, At the level of medical and social services: It is still "incidental" to get to the appropriate expert or centre for diagnosis or treatment. It is difficult to find even the services, because of the lack of suitable "pathways" and referral. There are long delays in obtaining the first appointment, resulting in defencelessness and regional irregularity. The overall consequence is the lack of access to medical and to social services. We also have difficulties with the supply of orphan medication and with the long duration of hospitalisations.

2, At the level of patient organisations: financial scarcity and uncertainty is typical and combined with inappropriate infrastructural background and human resources.

\section{Conclusions}

We need to continue our efforts for the formation of Centres of Expertise and their Networks together with the development of our National Plans. We also want to improve habilitation and rehabilitation services to compensate the social disadvantages. The relative low organisation level of patient organisations and the unsatisfactory level of their cooperation is also characteristic. More effective, professional operations associated with strategic approaches, with the help of national and international cooperation is necessary!

Correspondence: pogany@rirosz.hu

Hufferdis, Üllői út 82, Budapest H-1082, Hungary
Published: 19 October 2010

doi:10.1186/1750-1172-5-S1-O30

Cite this article as: Pogany: The present situation of Rare Diseases in Central/Eastern Europe? The role of patient organisations. Orphanet Journal of Rare Diseases 2010 5(Suppl 1):O30.
Submit your next manuscript to BioMed Central and take full advantage of:

- Convenient online submission

- Thorough peer review

- No space constraints or color figure charges

- Immediate publication on acceptance

- Inclusion in PubMed, CAS, Scopus and Google Scholar

- Research which is freely available for redistribution

Submit your manuscript at www.biomedcentral.com/submit
C Biomed Central 